\title{
CHARACTERIZATION AND TREATMENT OF LIQUID WASTES FROM SOME ANALYTICAL CHEMISTRY LABS BY USING SODIUM SULFIDE
}

\author{
Khalil, M. M. H. ${ }^{(1)}$; A. Razek T. M. ${ }^{(2)}$ and Atalla, Mona, S. \\ 1) Faculty of Science, Ain Shams University 2) Institute of Environmental \\ Studies and Research, Ain Shams University
}

\begin{abstract}
Chemical laboratories discharge their liquid wastes to the general sewerage network without treatment. This work aimed to remove heavy metals from inorganic liquid wastes generated from the laboratories of inorganic analytical chemistry. Liquid waste samples were collected from some analytical laboratories (refractory, cement and masonry materials). The method for treatment involve chemical precipitation of the heavy metals in the form of metal sulfides using sodium sulfide, which was added to the liquid wastes at different $\mathrm{pH}$ values, and then allowed to settle. Based on the results obtained in the current study, single precipitation at $\mathrm{pH}$ value equal to 7 using sodium sulfide is considered the best method to be used for the removal of heavy metals from the liquid wastes of inorganic chemistry laboratories. It can be seen that, for $\mathrm{Pb}, \mathrm{Zn}, \mathrm{Fe}$ and $\mathrm{Al}$, the removal efficiency reached $99.89 \%, 99.96 \%, 99.91 \%$, 99.99\%, respectively. In regards to $\mathrm{Cr}$ removal efficiency reached $45.03 \%$ at $\mathrm{pH} 5$ while at $\mathrm{pH} 11$ it reached $81.05 \%$. It can be concluded that the resulted effluent after treatment comply with the regulations set by law.
\end{abstract}

Keywords: Analytical labs, Heavy metals, lab effluents, Na2S. 
J. Environ. Sci.

Institute of Environmental Studies and Research - Ain Shams University

\section{INTRODUCTION}

The chemical analysis of ores, minerals and their products is of prime importance. Such analysis reveals the elemental content of ores, minerals and their products and determines its suitability and quality for different uses. Clays are used in the manufacture of clay bricks, cement, ceramics and porcelain. The quality of clays depends on some analytical parameters, namely, aluminum oxide, iron oxide and calcium oxide content. Sand is used in a multitude of industries, namely glass, electronics, and building materials (floor tiles, mortars, concrete and sand bricks). Silica and iron oxides determine the sand quality.

Other minerals such as bauxite, chromite, ilmnite, and hematite are used in the manufacture of aluminum and alumina refractories, chromic acids and chrome refractories, paints and steel manufacture, respectively (Welcher,1975).

The analysis of inorganic minerals (clays, sands, ores) requires the determination of its elemental contents such as $\mathrm{Si}, \mathrm{Fe}, \mathrm{Al}, \mathrm{Ti}, \mathrm{Ca}, \mathrm{Mg}, \mathrm{Na}$, and $\mathrm{K}$. Also, the quality of products manufactured from these minerals (glass and glass products, cement, refractories and ceramics etc...) requires the determination of the elements mentioned before.

Analysis of these materials (ore, minerals and their products) is carried out using carbonate fusion (for hard to dissolve materials) or acid dissolution to get the mother liquor. Such liquor is analyzed for its metal content using gravimetric, titrimetric (oxidation reduction, and complexmetric) and spectrophotometric methods. 
These analyses use some chemical reagents to be carried out e.g. standard potassium dichromate $\left(\mathrm{K}_{2} \mathrm{Cr}_{2} \mathrm{O}_{7}\right)$, potassium permanganate $\left(\mathrm{KMnO}_{4}\right)$, ethylene diamine tetraacetic acid (EDTA) and silver nitrate $\left(\mathrm{Ag} \mathrm{NO}_{3}\right)(\mathrm{Jeffery}$ et al.,1989).

The waste, containing heavy metals, of these analyses is discharged to sewerage system without treatment. Hexavalent chromium is of particular environmental concern due to its toxicity and mobility and is challenging to be removed from industrial wastewater.

It is a strong oxidizing agent that is carcinogenic and mutagenic and diffuses quickly through soil and aquatic environments, (Carlos et al ., 2012).

In contrast to organic pollutants in wastewater, heavy metals can only be removed by separation or converted to a chemically inert state (Charerntanyarak,1999; Alvarez-Ayuso et al., 2003; Kurniawan et al., 2006). The removal of heavy metals from waterwaste can be achieved by, for example, chemical precipitation, ion exchange, solvent extraction, ion flotation, adsorption and membrane filtration (Tuenay and Kabdasli, 1994; Baltpurvinset et., 1996; Lazaridis et al., 2001). of these, chemical precipitation is the most widely used method due to its simplicity of use ( $\mathrm{Li}$ et al., 2003; Duan and Gregory). In this approach, the dissolved metal ions are converted to the insoluble solid phases via a chemical reaction with a precipitant, for example, alkali or sulfide. The resultant precipitate is then separated from water by sedimentation and/or filtration or flotation (Matis et al., 2004., Zamboulis et al., 2004). 
Applying sodium hydroxide at $\mathrm{pH}$ values of 4 and 5 with further addition of sodium sulfide at $\mathrm{pH}$ values of 7 and 8 , respectively, decreased highly the dosage of the second precipitant, when it was exclusively applied. The best percentages achieved for metals removal were: lead, 100\%, chromium, 99.9\%, and zinc, 99.9\% (Marchioretto et al., 1996). Hydroxide precipitation using lime or caustic is the most commonly used form of chemical precipitation at wastewater treatment plants. The second is sulfide precipitation, which is more advantageous than hydroxide precipitation, once it can reduce hexavalent chromium to the trivalent state under the same process conditions required for metals precipitation, it allows for the precipitation of metals when chelating agents are present and most metals can be removed to extremely low concentrations at a single $\mathrm{pH}$.

Limitations of the process involve the potential hydrogen sulfide gas evolution and the concern for sulfide toxicity. However eliminating sulfide reagent overdose prevents formation of the odor causing hydrogen sulfide (EPA, 1998).

Nowadays, a combination of hydroxide and sulfide precipitation for optimal metals removal is being well considered. A common configuration is a two-stage process in which hydroxide precipitation is followed by sulfide precipitation with each stage followed by a separate solids removal step. This will produce the high quality effluent of the sulfide precipitation process while significantly reducing the volume of sludge generated and the consumption of sulfide reagent (EPA, 1998). 
Passive treatment systems (PTS) are one method used to treat chemical lab wastes. These systems allow the flow of water while improving its quality.( Cortina et al., 2003) and (Cravotta et al., 2003) described a PTS as crushed limestone that is placed in a buried bed to intercept chemical lab wastes. These systems have been evaluated at laboratory scale using batch and column experiments.( Simón et al .2005) and at field scale at several locations $\mathrm{PTS}$ have been proven adequate to increase $\mathrm{pH}$ and remove, $\mathrm{Pb}$ and Cd (Cravotta et al., 1999) .

Industrial activities give rise to large quantities of water waste containing toxic heavy metals.

The aim of this work is to investigate the possibility of treating liquid wastes generated from experiments of inorganic chemistry laboratory to remove heavy metals before discharging into public sewerage network. Also, to establish the optimum operation parameters to remove heavy metals (lead iron - zinc - chromium- aluminium) in liquid wastes resulting from chemical analysis laboratories.

\section{MATERIALS AND METHODS}

Materials: Waste samples were collected from some laboratories (refractory testing, cement and masonry material) liquid wastes. The liquid waste used in this work was generated from Chemistry Administration which is an inspection body belong to the ministry of industry.

The samples tested in these laboratories are the raw materials such as feldspars, dolomite, sand mineral and kaolinite minerals. 
Chemical analyses were carried out according to (Jeffery, et al.,1989). All chemicals used were of analytical grade. The chemicals used are ammonium chloride, ammonium hydroxide, ammonium nitrate, EDTA , 5sulfosalicylic acid, ammonium acetate and PAR[4-(2pyridylazo) resorcinol monosodium salt]. The $\mathrm{pH}$ of the liquid samples were analyzed by using $\mathrm{pH}$ meter. Quantitative chemical analysis were carried out according to .

Instrument: $\mathrm{pH}$ meter (Metrohm, 604 Swiss). Atomic absorption Spectrometry (A.A-600, PerkinElmer, USA).

\section{Methods:}

1-Determination of $\mathrm{Pb}, \mathrm{Fe}, \mathrm{Zn}, \mathrm{Cr}$ and $\mathrm{Al}$ in the waste samples before and after treatment was carried out using EDTA .

2-Treatment and precipitation experiments are carried out as follows

Adjustment of $\mathrm{pH}$ sample at 5, 7, 9, and 11 with the addition of $\mathrm{Na}_{2} \mathrm{~S}$ followed by filtration and analysis of the filtrate.

3 -After treatment (precipitation with the aforementioned precipitant) $\left(\mathrm{Na}_{2} \mathrm{~S}\right)$ the filtrate was subjected to AAS for heavy metals determination.

Results and Discussion: Chemical precipitation is widely used for the removal of heavy metals from inorganic waste water effluent. After adjusting the $\mathrm{pH}$ of the water waste, or adding chemical reagents to the dissolved metal ions where it is converted to insoluble form through a chemical reaction with the precipitating agent.

The reactions that involve heavy metal precipitation are presented in the following equations (Wang and et al., 2005) 


\section{$\mathrm{M}^{2+}(\mathrm{aq})+2 \mathrm{~S}^{-}(\mathrm{aq}) \rightarrow 2 \mathrm{MS} \downarrow$}

Where, $\mathrm{M}^{2+}$ represent the dissolved metal ions, while $\mathrm{OH}^{-}, \mathrm{S}^{-}$, and $\mathrm{CO}_{3}{ }^{-}$ ions are the precipitating agents. Table (1): represents the amounts of different metal ions in the sample of water waste .

Table (1): Concentrations of metal ions in the wastewater sample

\begin{tabular}{|c|c|c|c|c|c|}
\hline Materials & Pb & Fe & Zn & Cr & Al \\
\hline $\begin{array}{c}\text { Concentration of } \\
\text { metal }(\mathrm{mg} / \mathrm{l})\end{array}$ & 14.12 & 55.85 & 16.98 & 17.1 & 80.9 \\
\hline
\end{tabular}

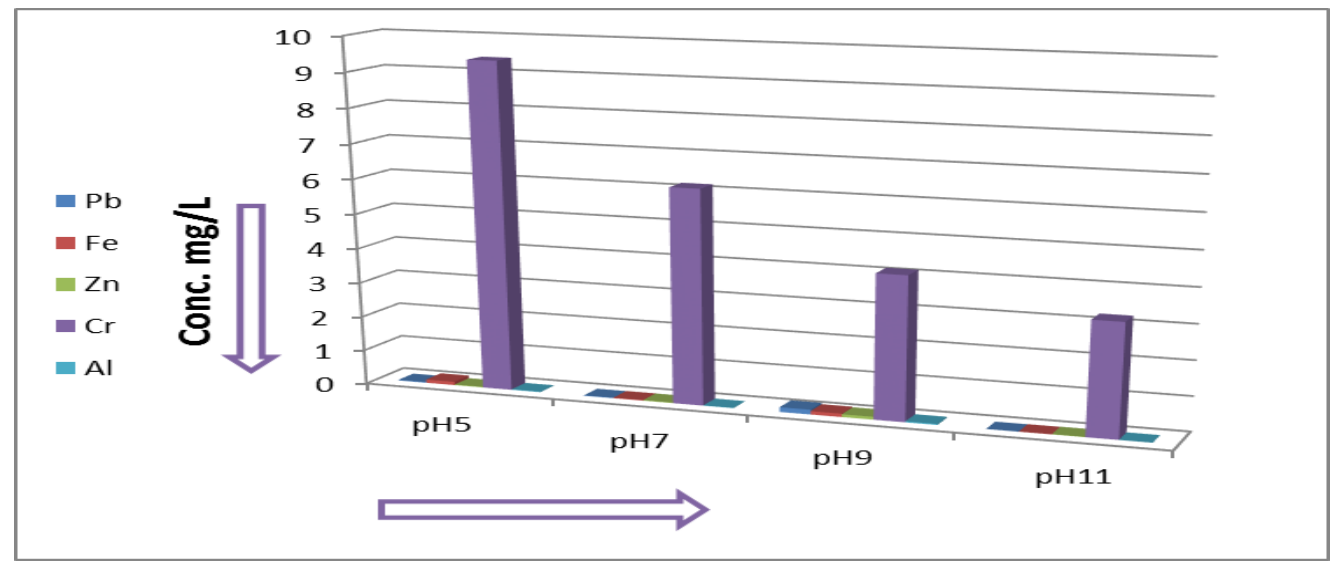

Figure (1): Precipitation of metal ions in the wastewater sample by sodium sulfide 
Table(2): The final concentration of the five metal ion at different $\mathrm{pH}$ using $\mathrm{Na}_{2} \mathrm{~S}$ and metal removal\% .

\begin{tabular}{|c|c|c|c|c|c|c|c|c|c|}
\hline \multirow[b]{2}{*}{$\begin{array}{l}\vec{\Xi} \\
\frac{\vec{\Xi}}{\Delta}\end{array}$} & \multirow[b]{2}{*}{ حُّ } & \multicolumn{2}{|c|}{ pH 5} & \multicolumn{2}{|c|}{ pH 7} & \multicolumn{2}{|c|}{ pH 9} & \multicolumn{2}{|c|}{ pH 11} \\
\hline & & ـ & $\begin{array}{l}\therefore \widehat{E} \\
\approx\end{array}$ & حـ & $\stackrel{\theta}{\approx}$ & ـ & $\begin{array}{l}\therefore S \\
\approx\end{array}$ & لـ & $\stackrel{\theta}{\approx}$ \\
\hline $\mathrm{Pb}$ & 14.12 & 0.019 & 99.87 & 0.015 & 99.89 & 0.138 & 99.02 & 0.002 & 99.99 \\
\hline $\mathrm{Fe}$ & 55.85 & 0.098 & 99.89 & 0.018 & 99.96 & 0.098 & 99.82 & 0.005 & 99.99 \\
\hline $\mathrm{Zn}$ & 16.98 & 0.018 & 99.97 & 0.016 & 99.91 & 0.082 & 99.52 & 0.009 & 99.98 \\
\hline $\mathrm{Cr}$ & 17.1 & 9.4 & 45.03 & 6.156 & 64. & 4.12 & 75.91 & 3.24 & 81.05 \\
\hline $\mathrm{Al}$ & 80.9 & 0.014 & 99.99 & 0.007 & 99.99 & 0.028 & 99.97 & 0.002 & 99.99 \\
\hline $\begin{array}{c}\text { Total } \\
\text { metals }\end{array}$ & 184.95 & 9.5 & & 6.2 & & 4.4 & & 3.3 & \\
\hline
\end{tabular}

( $\mathrm{R}=$ removal, $\mathrm{AT}=$ after treatment $)$

When sodium sulfide was used the total concentration of heavy metals rapidly decreased at the different tested values of $\mathrm{pH}$.

It can be seen that, for the four metals $\mathrm{Pb}, \mathrm{Zn}, \mathrm{Fe}$ and $\mathrm{Al}$ the removal efficiency reached the optimum at $99.49 \%$ while for $\mathrm{Cr}$ ion the efficiency was lower as $45.03 \%$ at $\mathrm{pH}$ value equal to 5 and $81.05 \%$ at $\mathrm{pH}$ value of 11 .

Results shown in Figure (1) indicated that, the residual concentrations of $\mathrm{Pb}, \mathrm{Zn}, \mathrm{Fe}$ and aluminum at $\mathrm{pH}$ value equal to 7 were reduced to $0.015 \mathrm{mg} / \mathrm{L}$, $0.0018 \mathrm{mg} / \mathrm{L}, 0.006 \mathrm{mg} / \mathrm{L}$ and $0.007 \mathrm{mg} / \mathrm{L}$ respectively, at $\mathrm{pH}$ value equal to 7 was the best treatment.

Comparison of the highest removal with regulatory limits: The results of treatment trials were compared with limits stated in the Egyptian law no. 93/1962 and its amendments that impose controls on the effluent of wastewater to public utility sewer systems (sewage network) and Egyptian 
decree 44/2000, that are related to the effluent wastewater poured into sewage systems.

To compare the obtained results of the current study with the regulatory limits, the concentration of different elements has to be used in the comparison.

Table (3): comparison between the obtained results of the current study with the regulatory limits.

\begin{tabular}{|l|c|c|c|c|c|c|}
\hline & $\mathbf{P b}$ & $\mathbf{F e}$ & $\mathbf{Z n}$ & $\mathbf{C r}$ & Al & total \\
\hline $\begin{array}{l}\text { Treatment By } \\
\mathrm{Na}_{2} \mathrm{~S}\end{array}$ & 0.015 & 0.018 & 0.016 & 2.005 & 0.007 & 6.2 \\
\hline $\begin{array}{l}\text { Egypt's } \\
\text { regulation mg / }\end{array}$ & 0.1 & 0 & 0 & 0 & 0 & 4.8 \\
\hline
\end{tabular}

The best treatment in the case of using sodium sulfide and $\mathrm{pH} 7$.

The collected precipitate (solid) can be oven dried and disposal as a hazardous solid waste.

\section{CONCLUSIONS}

It can be the best concluded that the best treatment conditions to remove heavy metals by using sodium sulfide is at $\mathrm{pH} 7 \mathrm{f}$ or the removal of heavy metals from liquid lab effluents . This technique was able to remove $\mathrm{Pb}, \mathrm{Zn}$, $\mathrm{Fe}$ and $\mathrm{Al}$. The removal efficiency reached 99.89\%, 99.96\%, 99.91\%, 99.99\%, respectively . Except the Cr the best removal efficiency $81.05 \%$ at $\mathrm{pH}$ value equal to11.Concentrations of these heavy metal elements in liquid waste after treatment were below the limits of the Egyptian law 93 for the year 1962. 


\section{REFERENCES}

Cortina, J. L.; Lagreca, I. J. and De Pablo, J. (2003): Passive in situ remediation of metal-polluted water with caustic magnesia evidence from column experiments, Environ. Sci. Technol., 37, 1971-1977.

Carlos, E.; Barrera-Díaza,; Lugo-Lugoa, B. and Bryan Bilyeuc (2012): A review of chemical, electrochemical and biological methods for aqueous Cr(VI) reduction. Journal of Hazardous Materials , 223$2241-2$.

Cravotta, C. (2003): Size and performance of anoxic limestone drains to neutralize acidic mine drainage A.;Environ,Qual, J.; 32, 12771289.

Cravotta, C. A. and Trahan, M. K. (1999) :limestone drains to increase pH and dissolved mtals from acidic mine drainage, Appl. Geochem. $14,581-606$.

Charerntanyarak, L. (1999): Heavy metals removal by chemical coagulation and precipitation, Water Sci. Technol, 39, 135-138.

Environmental Protection Agency EPA - (1998): Development Document for the CWT Point Source Category, Chapter 8: Wastewater Treatment Technologies.

Jeffery,G. H.;Bassett, J.;Mendham, J.and Deeney, R. C.(1989): Vogel's Textbook of chemical analysis ,Longman Scientific \& Technical, Copublished in the United States with John Wiley \& Sons, Inc., New York,pp.324-337.

Li, Y. J.; Zeng, X. P. and Liu, Y. F. ( 2003): Study on the treatment of copper-electroplating wastewater by chemical trapping and flocculation, Sep. Purif. Technol. 31, 91-95.

Marchioretto , M. M. (1996): Optimization of chemical dosage in heavy metals precipitation in anaerobically digested sludge. XXVIII Congreso Interamericano de Ingeniería Sanitaria y Ambiental Cancium , Mexico ,27al 31de octuber, 2002. 
Matis, K. A.; Zouboulis, A. I. and Gallios, G. P. ( 2004): Application of Flotation for the separation of metal-loaded zeolite.Chemosphere, $55,65-72$.

Shrivastava, R.; Upreti, R .K. and Chaturvedi, U.C. (2003 ):Various cells of the immune system and intestine differ in their capacity to reduce hexavalent chromium, FEMS Immunology \& Medical Microbiology.38,65-70.

Simón, M.; Martín, F.; García, I.; Bouza,P.; Dorronsoro,C.\& Aguilar, J. (2005): Interaction of limestone grains and acidic solutions from the oxidation of pyrite tailing, Environ. Pollut.135: 65-72.

Tuenay, O. (2003): Developments in the application of chemical technologies to wastewater treatment, Water Sci. Technol. 48, 43-52.

Wang, L .K.; Vaccari, D . A. Li. Y. ; Shammas, N.K.; Wang, L.K.; and., Hung, N. K. (2005)and Chemical Precipitation, in physiochemical treatment proceses ,Humana press,Trrowa, New Jersy, $1^{\text {st }}$ edition,pp. 141-150.

Welcher, F. J. (1975): Standard methods of chemical analysis, Huntington, Van Nostrand Reinhold Inc.,U.S... ${ }^{\text {th }}$ edition. 


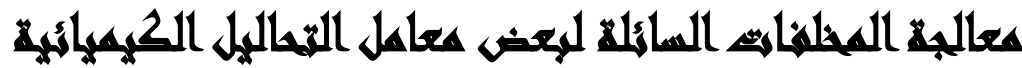

[r]

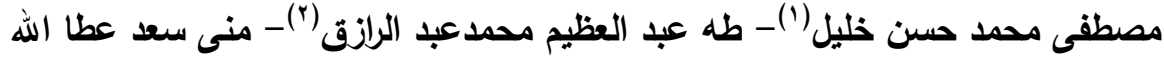

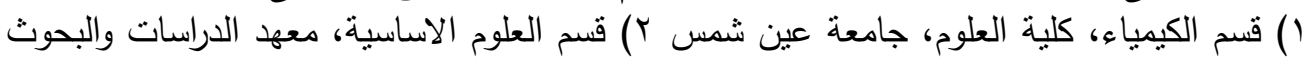

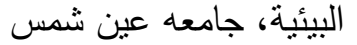

\section{المهرتيلى}

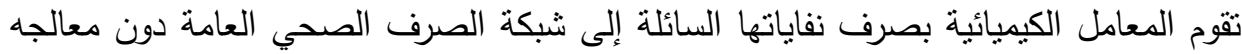

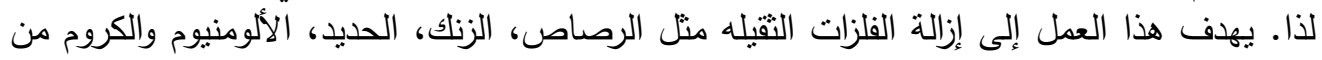

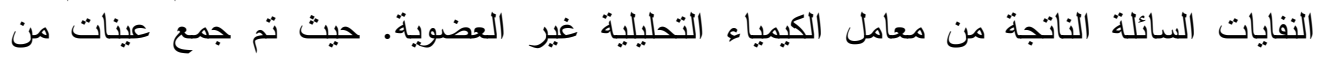

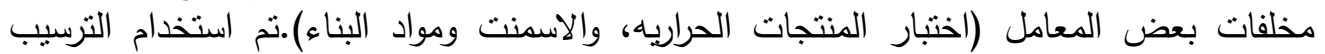

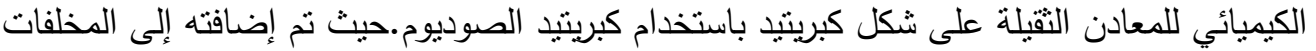

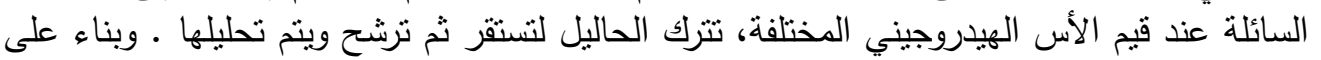

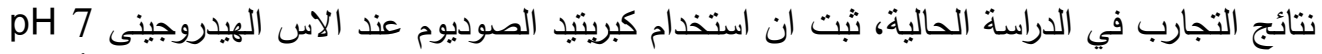

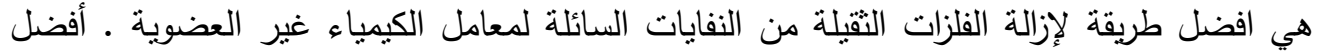

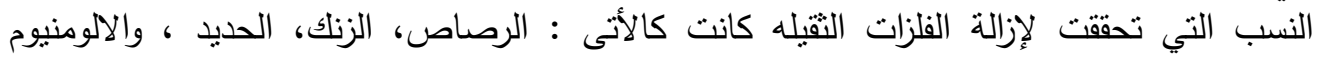

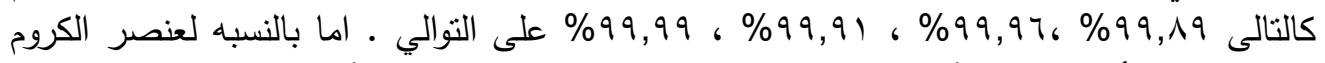

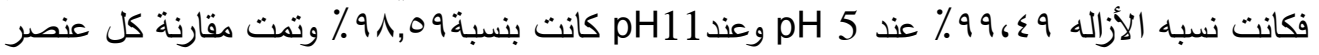

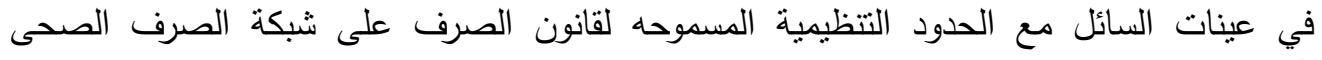
المصرى . 